\title{
Hydrogeology of the Hidden River Groundwater Basin, Horse Cave, Hart County, Kentucky
}

\author{
Cesalea N. Osborne \\ Department of Geography and Geology \\ Western Kentucky University \\ April $12^{\text {th }}, 2018$
}




\section{Geographic Boundaries in Karst}

- 263 watersheds transcend the political boundaries of two or more countries, many of which lie in karst regions (Jarvis et al. 2005).

- Karst makes up 15-20\% of the Earth's ice-free landscape and karst aquifers provide $25 \%$ of the world's population with drinking water (Palmer 2007).

- Conflicts regarding transboundary water resources are based on:

- Boundary location

- Distribution

- Availability

- Quality

- Examples include:

- Southeastern Europe (distribution) (Milanović 2016)

- Yucatán Peninsula (availability) (Bauer-Gottwein et al. 2011)

- South-central Kentucky (quality) (Quinlan and Rowe 1977) 


\section{South-Central Kentucky Karst}

- Three physiographic regions: Mammoth Cave Plateau, Dripping Springs Escarpment, Pennyroyal Plateau

- Characterized by a shallow, intensely karstified carbonate aquifer

- Extensive karst developed in the Girkin, Ste. Genevieve and St. Louis formations
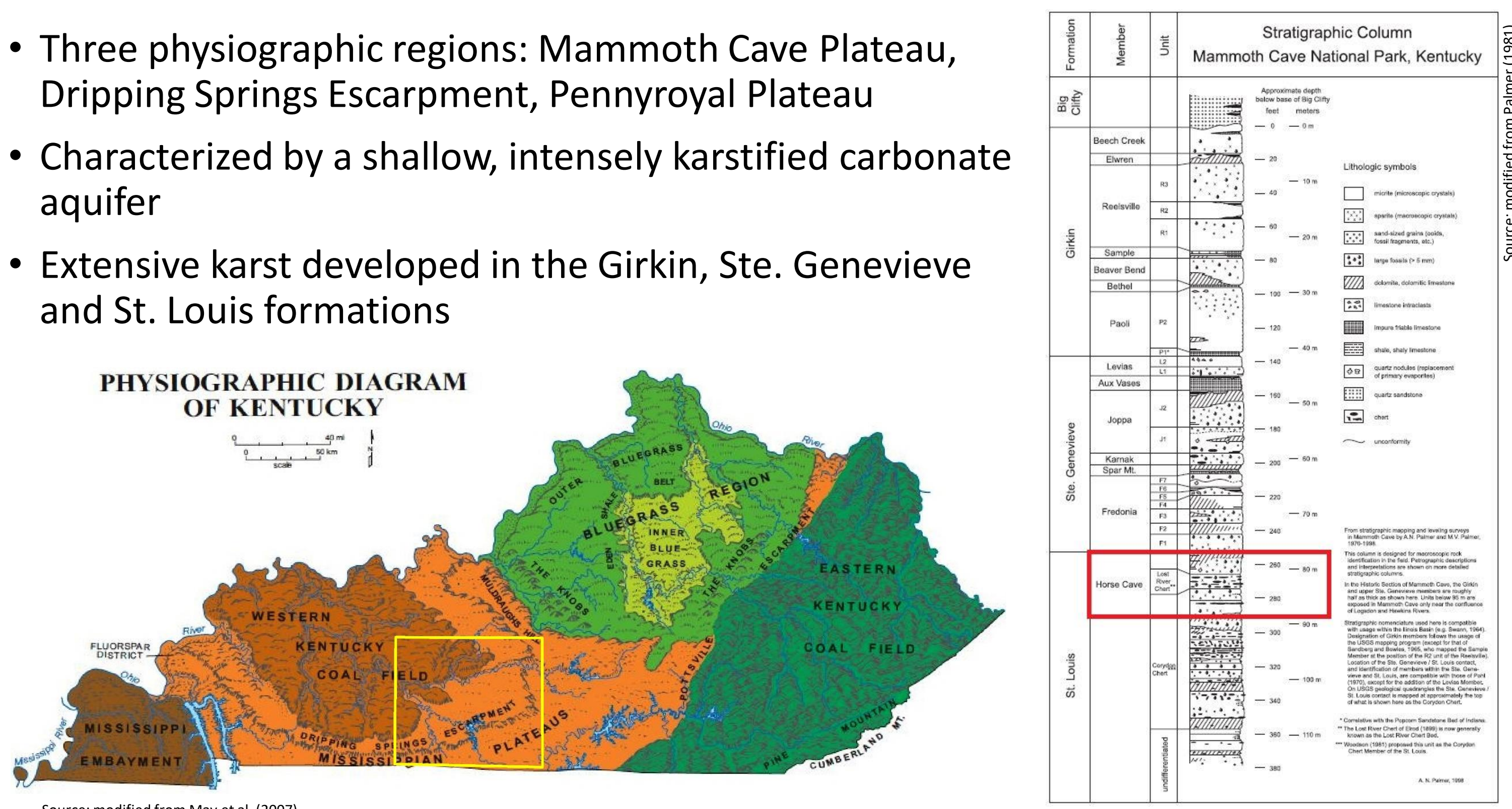


\section{Groundwater Basin Delineation in South-Central Kentucky}

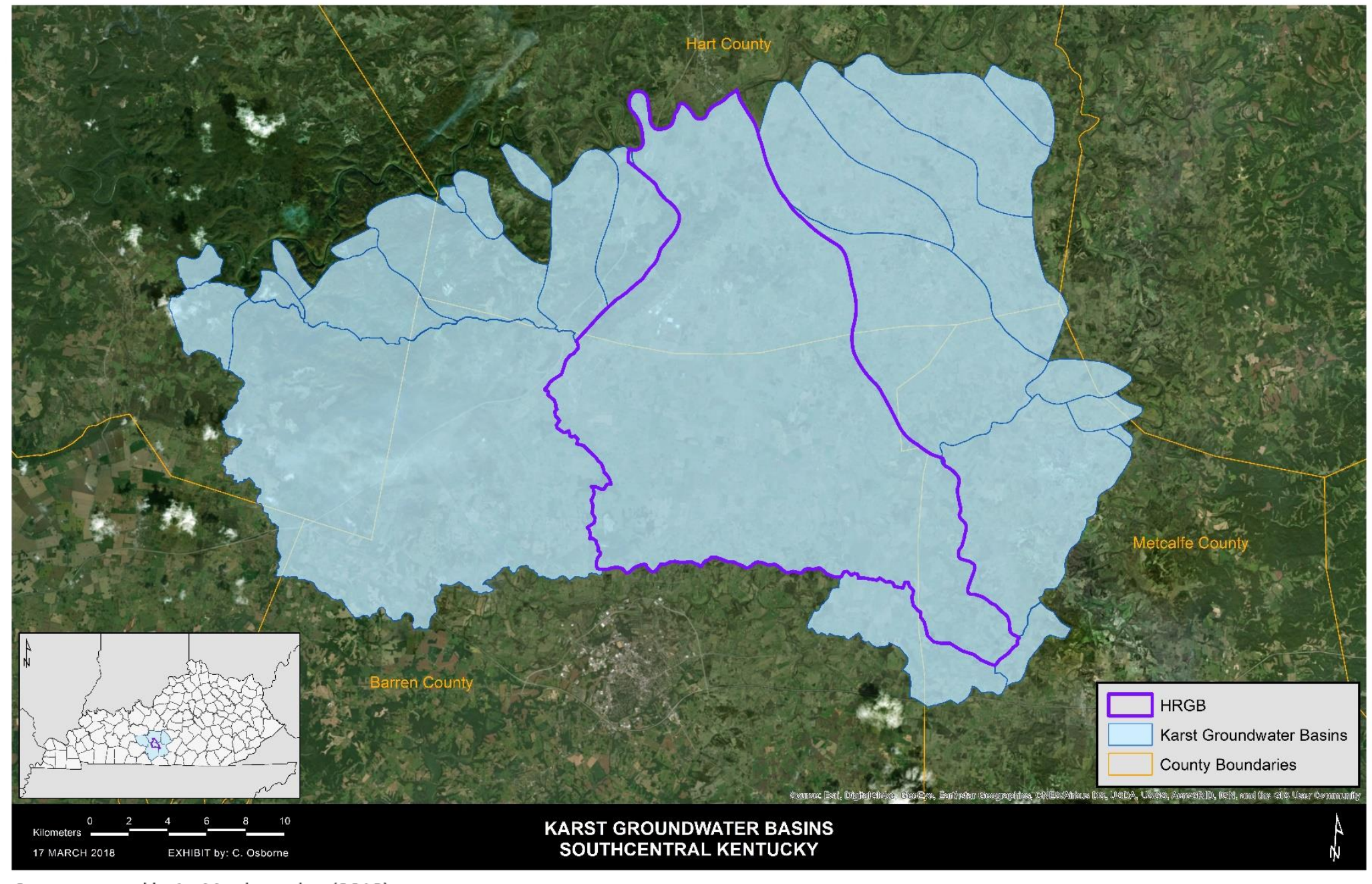

- >500 dye traces from 1975-1987 to determine sources of contamination (Quinlan and Rowe 1977)

- Delineated 28 major groundwater basins

- Of 28, Hidden River was the most anthropogenically impacted (White 1989)

- Transboundary groundwater basin $\rightarrow$ spans multiple counties in south-central Kentucky 
- The Hidden River groundwater basin includes:

- L\&N Cave

- Hidden River Cave

- Hidden River Complex

- Resurges at 46 springs along the Green River

- Historically, waste from Cave City and Horse Cave included:

- Injection of sewage, heavy metals, creamery waste, oil refinery waste, etc. into sinkholes (Lewis 1995)

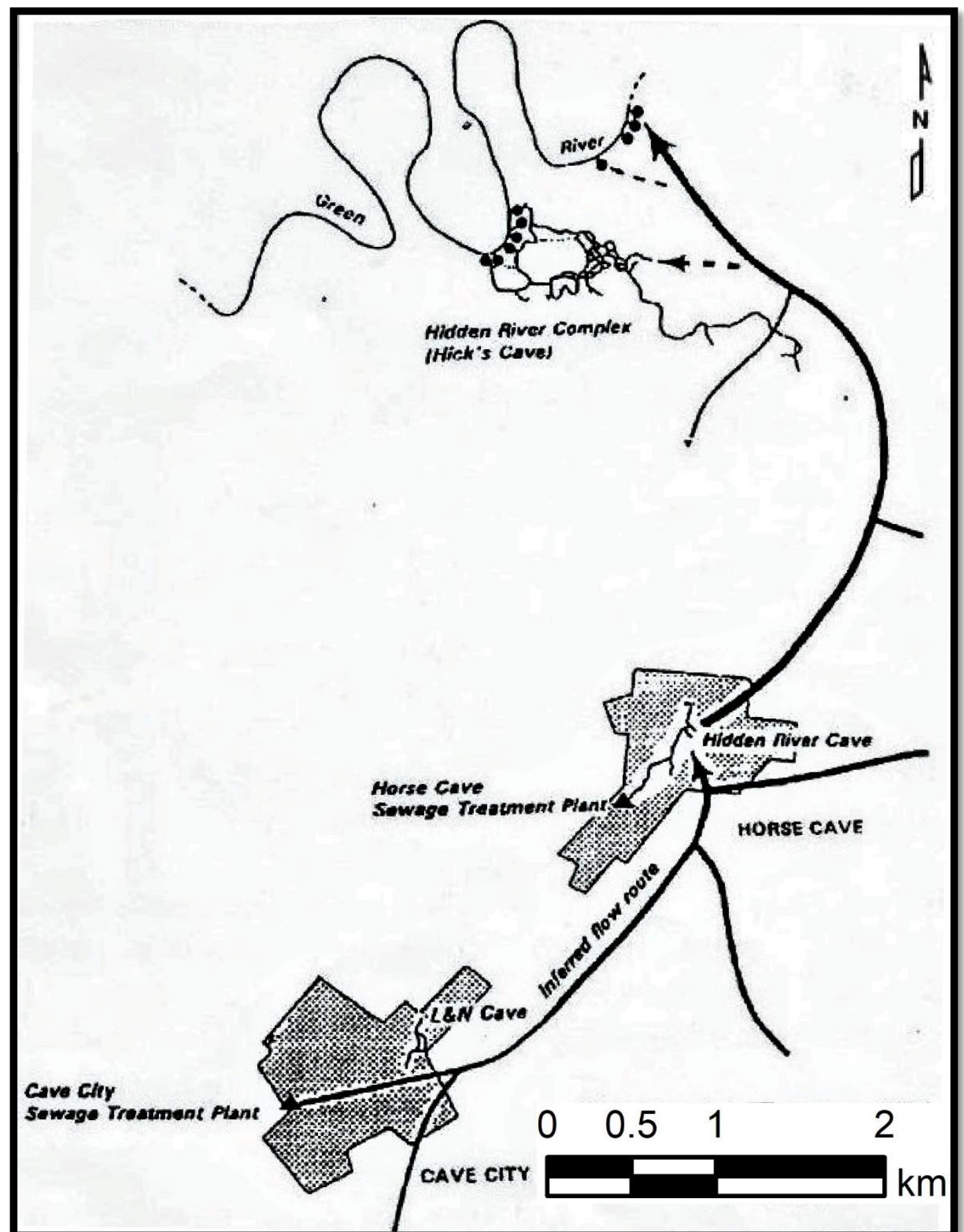




\section{Research Question and Hypothesis}

How does local land-use impact recharge to Hidden River cave?

- Changes in land-cover have altered recharge relationships with Hidden River Cave

- Features that may facilitate recharge include sinkholes, injection wells and storm drains (Raedts and Smart 2015) 


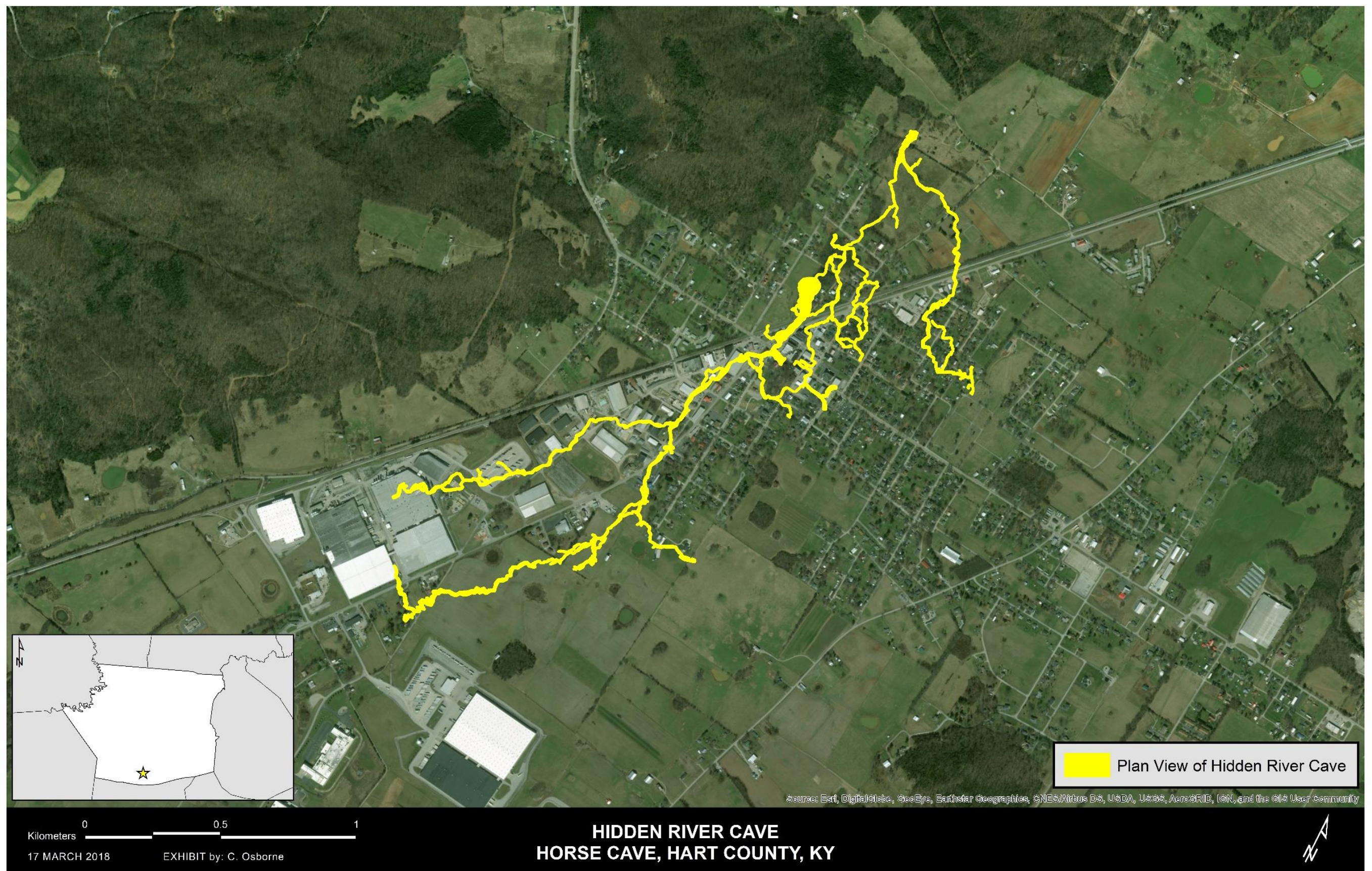




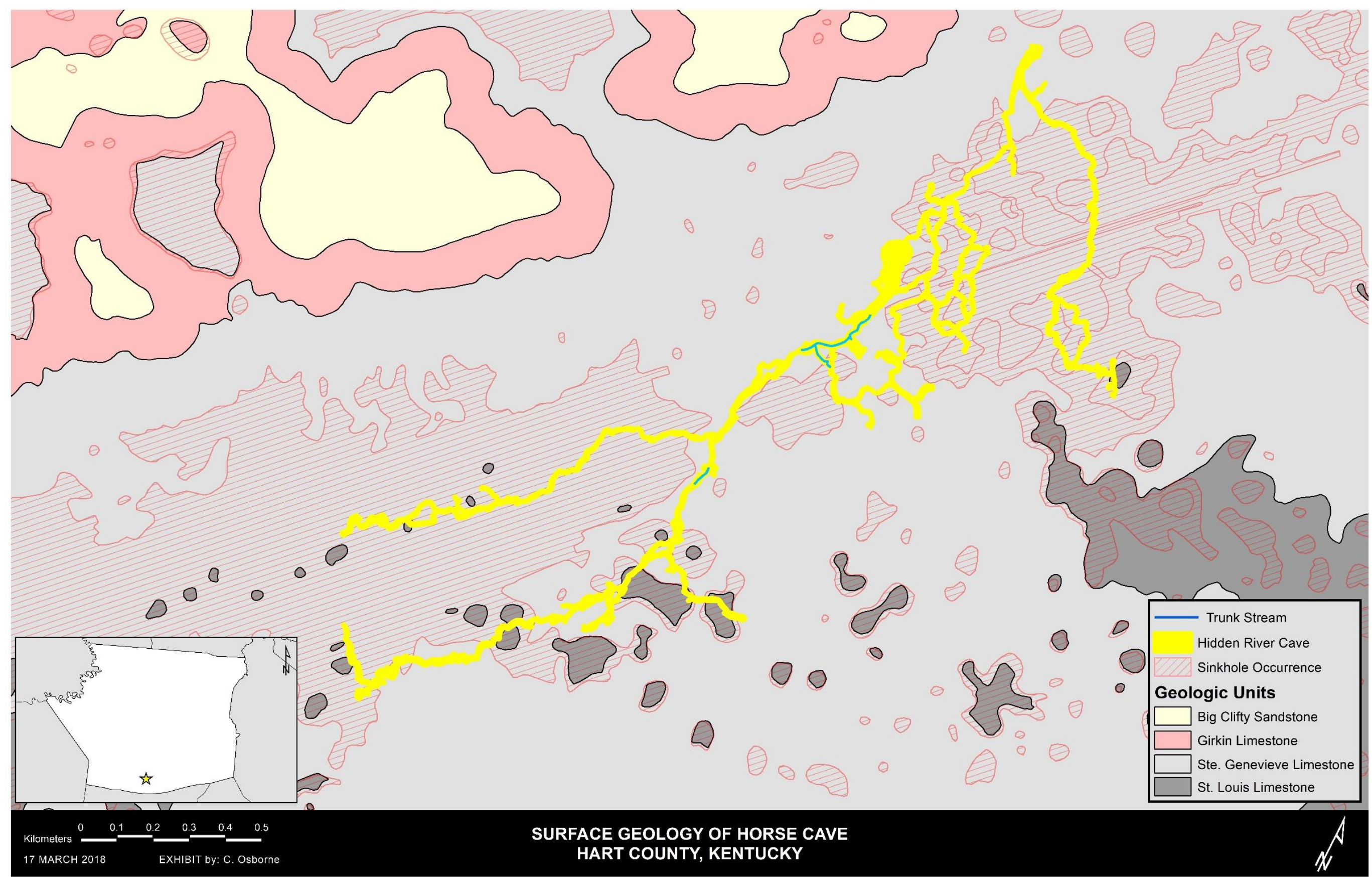




\section{Methodology}

1. Karst Hydrogeologic Inventory (KHI)

- Surface/subsurface survey

- Base map construction

2. Discharge measurements

- To determine if multiple tributaries contribute flow to the main cave stream

3. Groundwater dye tracing

- Background fluorescence monitoring

- Dye injection

4. Geographic Information Systems (GIS) analysis

- Land use analysis

- 3D modeling of subsurface recharge 


\section{Cave Survey}

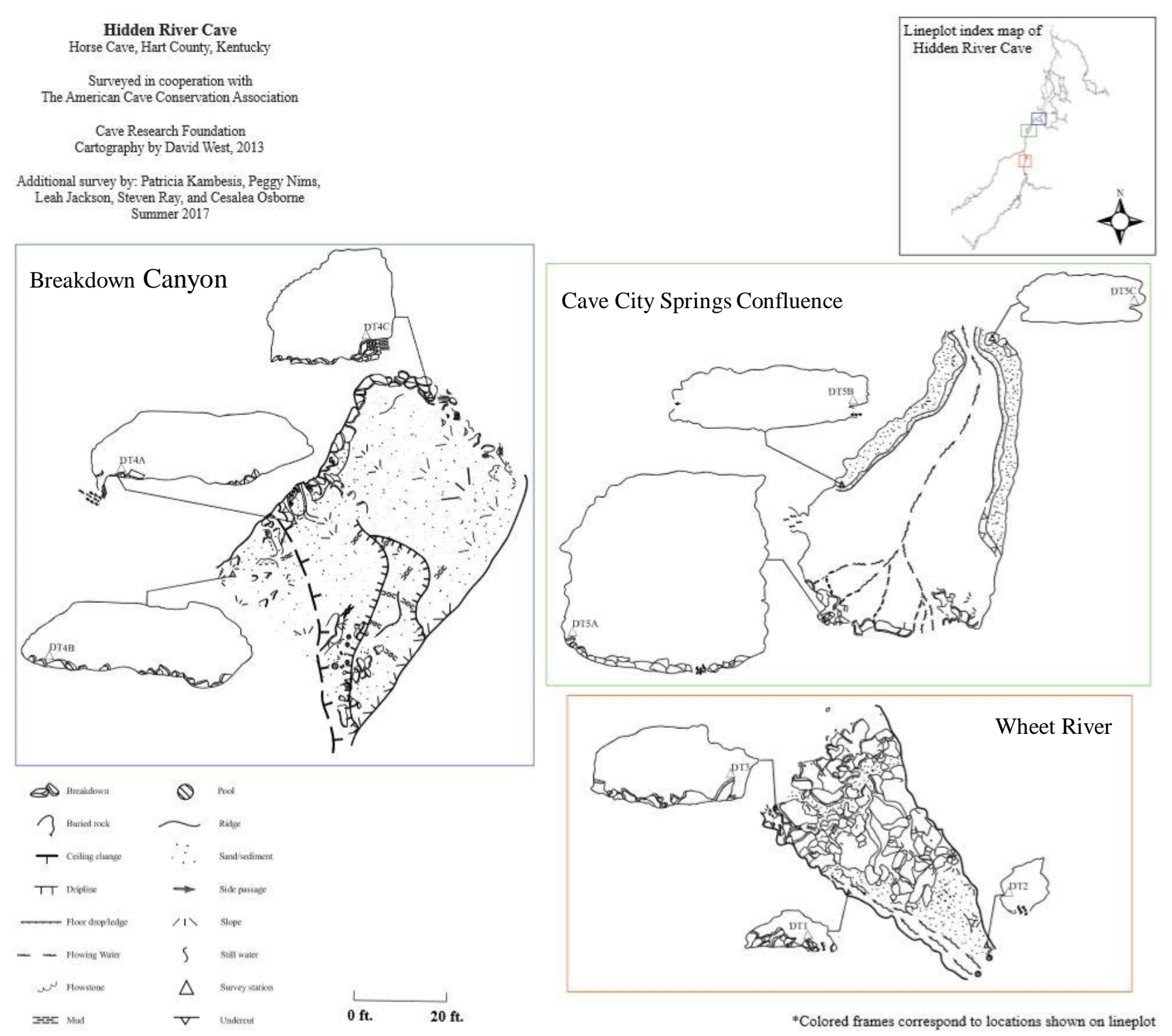




\section{$\mathrm{KHI}$ and Groundwater Dye Tracing}

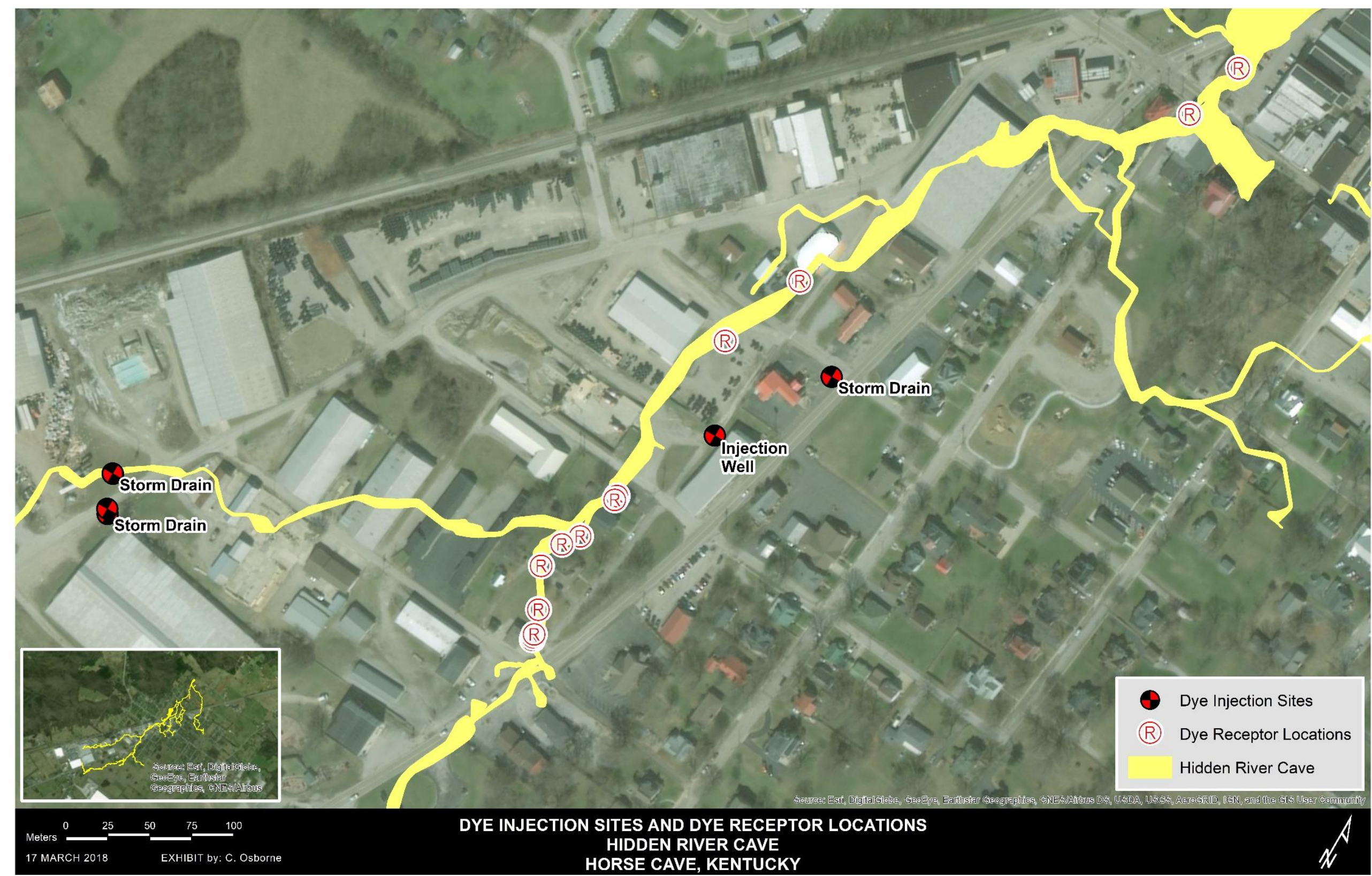




\section{Results of Background Analysis}

-6-dye background analysis: OB, FL, EO, R28, RWT, SRB

- Several samples contained OB and FL (Raedts and Smart 2015)

- Background fluorescence at 7 sites (OB, FL, R28, RWT)

- EO, RWT and SRB to be used for dye injection

\begin{tabular}{|c|c|c|c|c|c|c|c|c|c|c|c|c|c|c|c|c|c|c|c|}
\hline \multirow[t]{2}{*}{ Lab ID } & \multirow[t]{2}{*}{ Feature Name } & \multicolumn{3}{|c|}{ Tinopal CBS-X } & \multicolumn{3}{|c|}{ Fluorescein } & \multicolumn{3}{|c|}{ Eosine } & \multicolumn{3}{|c|}{ D\&C Red 28} & \multicolumn{3}{|c|}{ Rhodam ine WT } & \multicolumn{3}{|c|}{ Sulphorhodamine B } \\
\hline & & Results & Conc in $\mathrm{ppb}$ & $\begin{array}{l}\text { Peak Center } \\
(\mathrm{nm})\end{array}$ & Results & Conc in $\mathrm{ppb}$ & $\begin{array}{c}\text { Peak Center } \\
(\mathrm{nm})\end{array}$ & Results & Conc in $p p b$ & $\begin{array}{l}\text { Peak Center } \\
(\mathrm{nm})\end{array}$ & Results & Conc in $p p b$ & $\begin{array}{c}\text { Peak Center } \\
(\mathrm{nm})\end{array}$ & Results & Conc in $\mathrm{ppb}$ & $\begin{array}{c}\text { Peak Center } \\
(\mathrm{nm})\end{array}$ & Results & Conc in $\mathrm{ppb}$ & $\begin{array}{l}\text { Peak Center } \\
(\mathrm{nm})\end{array}$ \\
\hline 바-001-0 & WHEET RIVER & ND & 1.532 & NPI & ND & 0.052 & NPI & & & & & & & & & & & & \\
\hline El-002-0 & WHEET RIVER B & B & 1.131 & 403.6,POR & ND & 0.044 & NPI & & & & & & & & & & & & \\
\hline EL-003-0 & WHEET RIVER C & IB & 1.023 & 399.4 & ND & 0.038 & NPI & & & & & & & & & & & & \\
\hline E+-005-0 & WHEET DRIP & IB & 3.799 & 401.6 & & & & & & & IB & 0.753 & 559.6 & B & 0.373 & 559.6,POR & & & \\
\hline EH-006-0 & BOARD ROOM & IB & 4.757 & 401.4 & B & 0.012 & 522.6,POR & & & & ND & 0.550 & NPI & ND & 0.260 & NPI & & & \\
\hline E+007-0 & WATERFALL ROOM & ND & 0.599 & NPI & & & & ND & 1.761 & NPI & & & & & & & ND & 0.027 & NPI \\
\hline EL-008-0 & WELL CASING A & B & 1.096 & 404.8,POR & ND & & NPI & & & & IB & 7.555 & 564.6 & IB & 3.826 & 564.6 & & & \\
\hline El-009-0 & WEL L CASING B & IB & 0.721 & 395.6 & ND & 0.027 & NPI & & & & IB & 0.962 & 563.6 & IB & 0.485 & 563.6 & & & \\
\hline El-010-0 & WELL CASING C & IB & 0.885 & 398.6 & IB & 0.120 & 514.4 & & & & & & & & & & & & \\
\hline El-011-0 & BREAKDOWN DRIP & B & 0.549 & 390.8,POR & ND & & NPI & & & & ND & 0.053 & NPI & ND & 0.021 & NPI & & & \\
\hline El-012-0 & BREAKDOWN CANYON & ND & 0.493 & NPI & & & 525.8,POR & ND & 0.043 & NPI & & & & & & & & & \\
\hline EL-013-0 & SOUTH RIVER & ND & 0.296 & NPI & IB & 0.026 & 521.0 & & & & & & & & & & & & \\
\hline El-014-0 & EAST RIVER & & & & ND & 0.031 & NPI & ND & 0.030 & NPI & & & & & & & & & \\
\hline
\end{tabular}




\section{Completed Dye Injections}

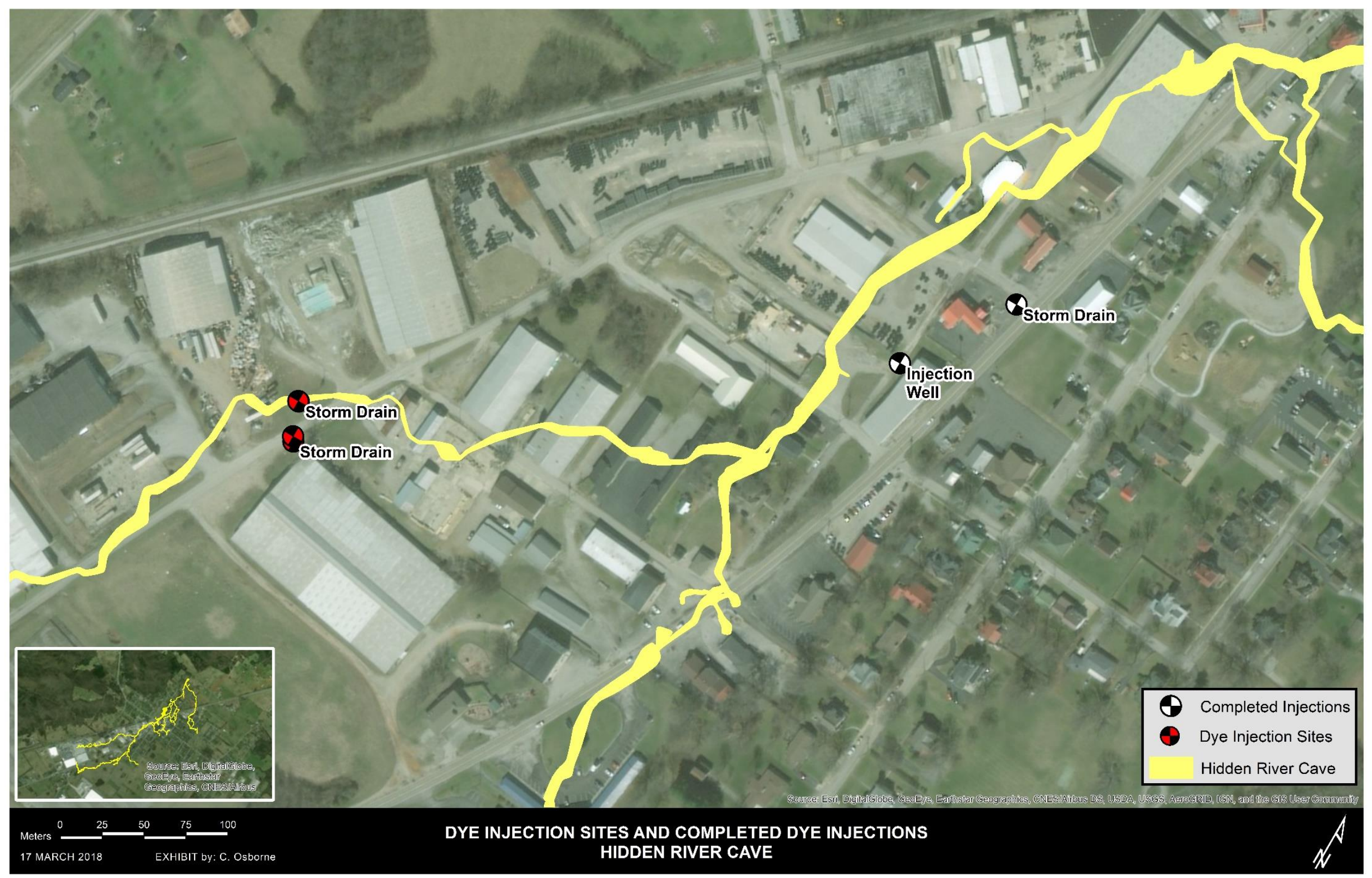




\section{Discharge Measurements}

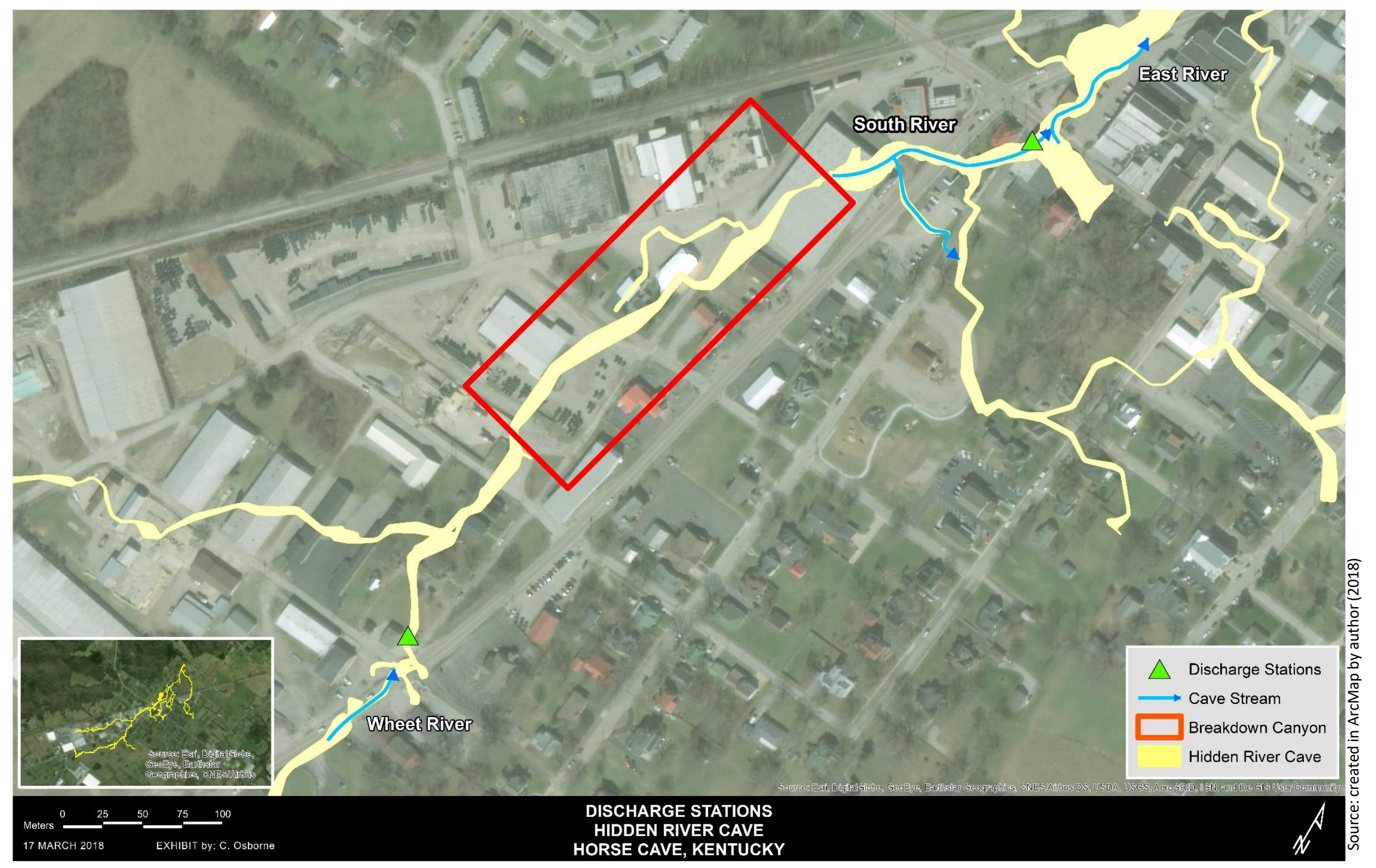




\section{Preliminary Discharge Data}

Cave Stream Discharge

Hidden River Cave

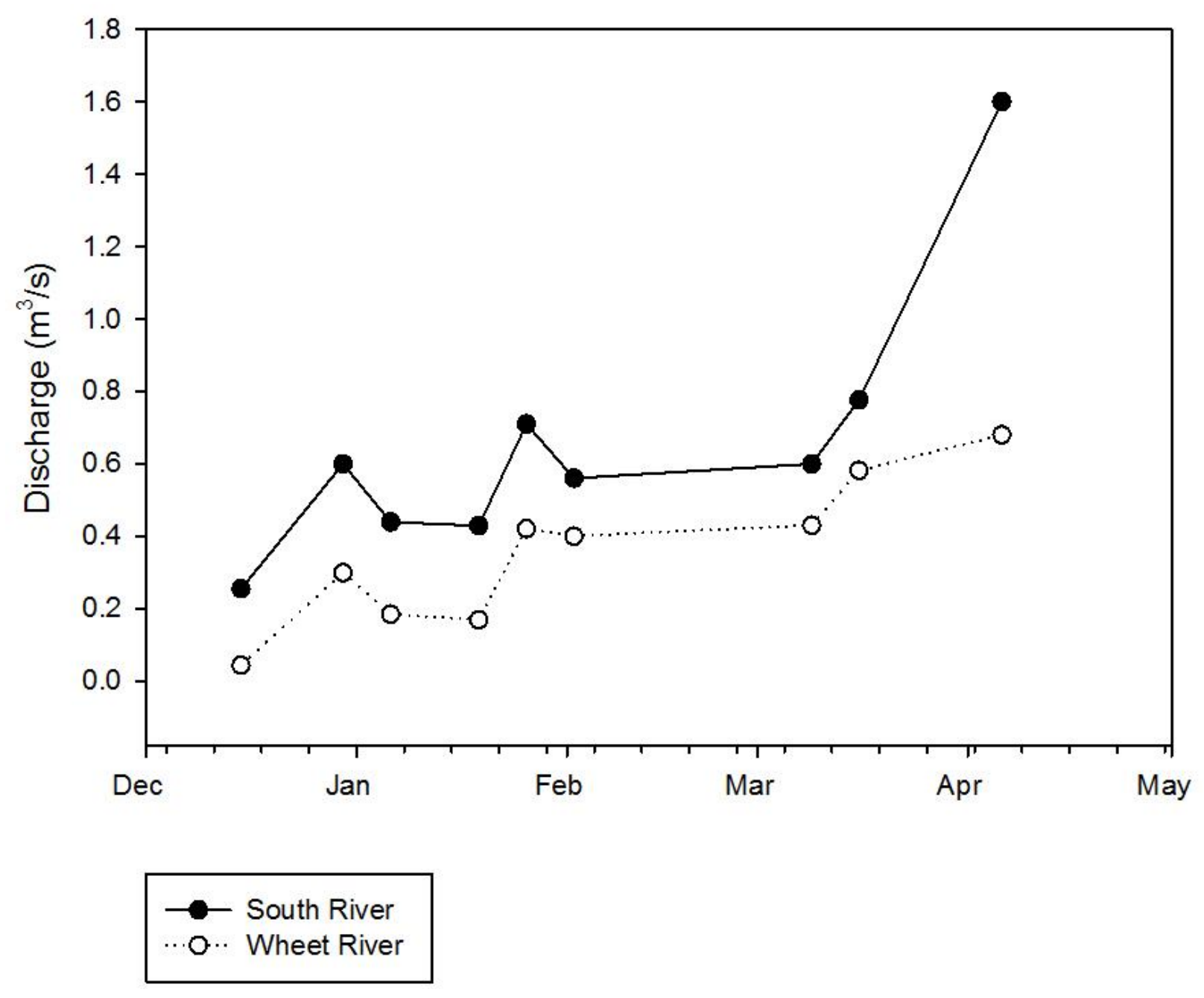



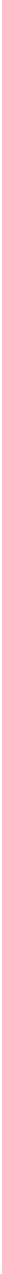


\section{Land-use Analysis}

- Remote sensing using supervised and unsupervised classification

-Aerial imagery from USGS GloVis

- Calculation of percentage of developed areas

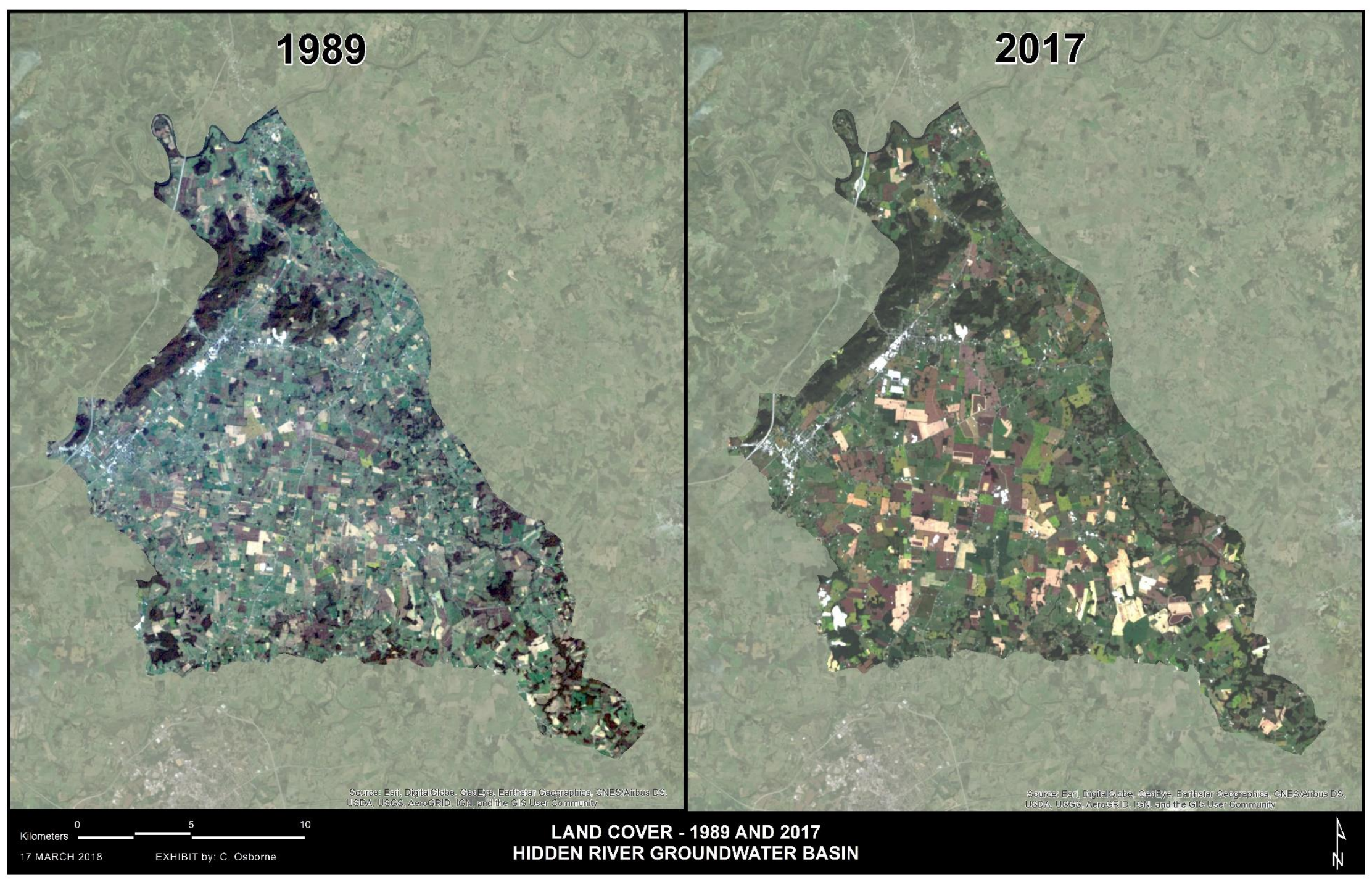




\section{D Modeling with ArcScene}

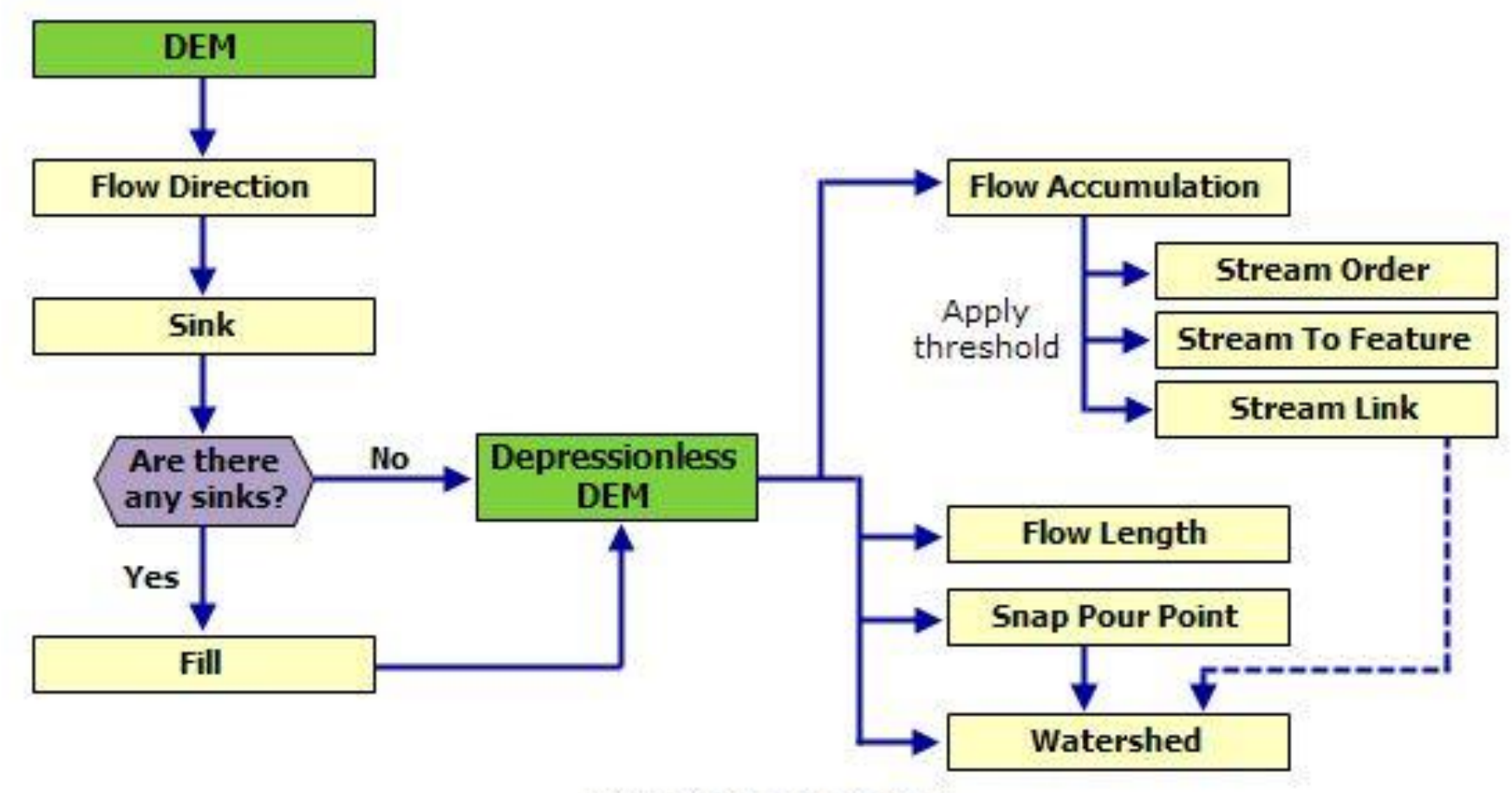

Hydrological modeling flowchart

Source: ESRI (2017)
- Model recharge to Hidden River Cave

- 30ft DEM from KyGeoNet

- Watershed analysis in ArcMap

- Determine points of water accumulation

- Inclusion of dye trace data

- ArcScene

- produce a 3D model of recharge to Hidden River Cave 


\section{Why is this study important?}

1. Refine existing dye trace maps from Quinlan and Rowe (1977) to provide more detail on groundwater recharge to the Hidden River groundwater basin

2. Discharge measurements can determine if more tributaries exist, which can provide more information about contaminant pathways

3. Documentation of changes in land-use can provide data about the impacts that development may have on recharge

4. Three-dimensional model of recharge to Hidden River Cave can also provide details of overall hydrogeology

5. Provide data and graphics to enhance the educational displays at the American Cave Museum

6. Provide scientific data toward informed management of Hidden River Cave

7. Methods can be used in other transboundary karst regions 


\section{"Be Kind to Karst!" - Aley (2015)}

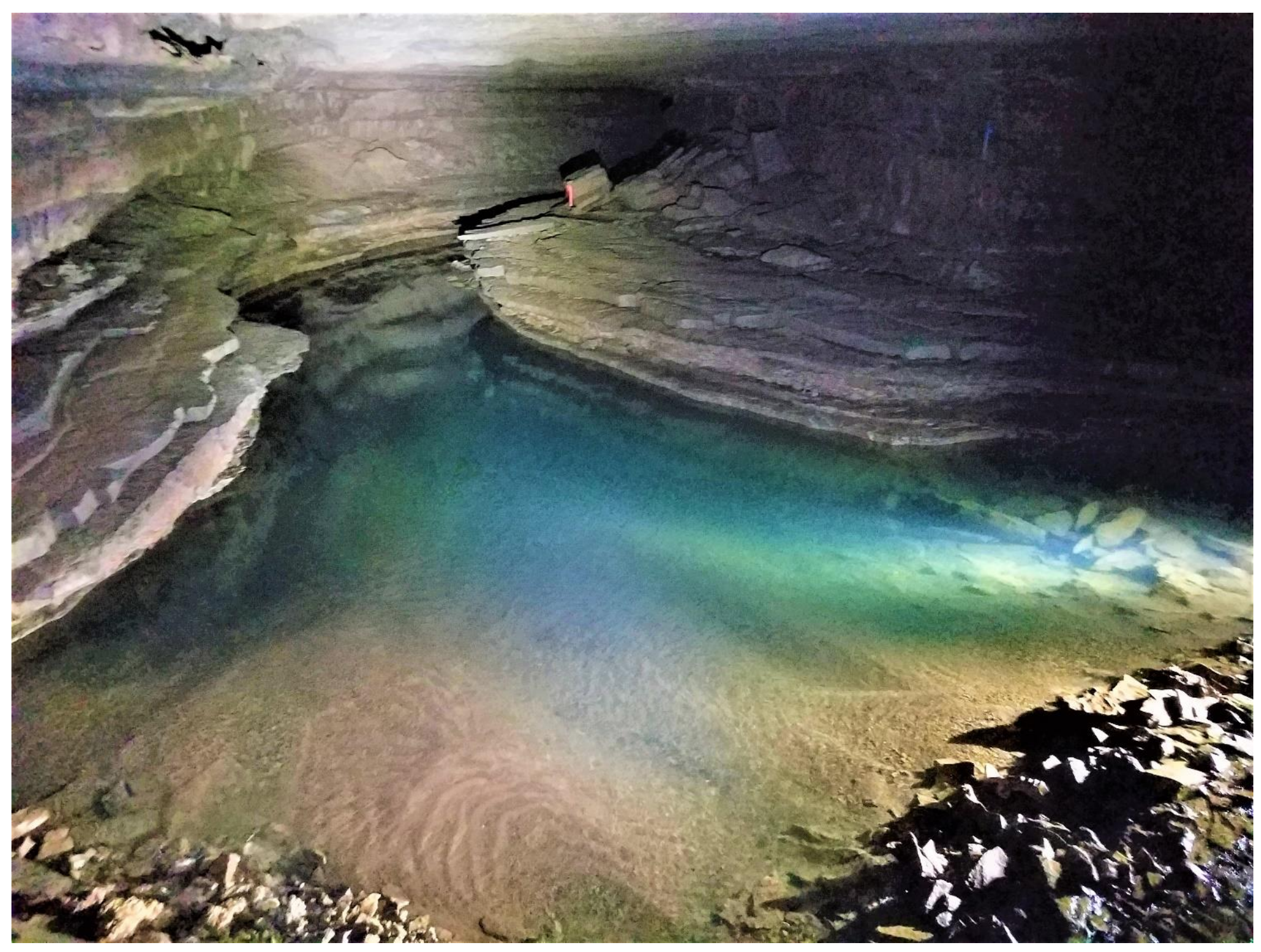




\section{References}

Blair, R., Goodmann, P., Marbert, B., O'dell, P., Ray, J. 2012. Integrated Surface Water and Groundwater Assessment of Large Springs in the Green River Basin (BMU4, Round 2). Frankfort, KY: Kentucky Division of Water.

Environmental Systems Research Institute (ESRI) 2017. An Overview of the Hydrology Toolset. Redlands, CA: Esri. Available at: https://pro.arcgis.com/en/pro-app/tool-reference/spatial-analyst/an-overview-of-the-hydrologytools.htm

Jarvis, T., Giordano, M., Puri, S., Matsumoto, K., Wolf, A. 2005. International Borders, Ground Water Flow, and Hydroschizophrenia. Groundwater, 43(5), 764-770.

Lewis, J. 1995. The Devastation and Recovery of Caves and Karst Affected by Industrialization. Proceedings of the 1995 National Cave Management Symposium, 214-227.

Palmer, A.N. 1981. A Geological Guide to Mammoth Cave National Park. Teaneck, NJ: Zephyrus Press.

Quinlan, J.F., Rowe D.R. 1977. Hydrology and Water Quality in the Central Kentucky Karst: Phase I. Research Report No. 101. Lexington, KY: University of Kentucky.

Raedts, C., Smart, C. 2015. Tracking of Karst Contamination Using Alternative Monitoring Strategies: Hidden River Cave, Kentucky. Proceedings of the 14th Multidisciplinary Conference on Sinkholes and the Engineering and Environmental Impacts of Karst, 327-336.

White, E.L., White, W.B. 1989. Karst Hydrology: Concepts from the Mammoth Cave Area. New York, NY: Van Nostrand Reinhold. 